\section{アユの細菌性出血性腹水病に対する アセトン乾燥菌体を用いた経口免疫}

金辻宏明* ·二宮浩司・ 山本充孝

(2006年 5 月15日受付)

\section{Vaccination with Acetone-dry Bacterin against Bacterial Hemorragic Ascites of Ayu Plecoglossus altivelis}

\author{
Hiroaki Kintsuji*, Koji Ninomiya and \\ Michitaka Yamamoto
}

Shiga Prefectural Fisheries Experimental Station, Hikone, Shiga 522-0057, Japan

(Received May 15, 2006)

\begin{abstract}
We developed an acetone-dry oral bacterin against bacterial hemorragic ascites of ayu Plecoglossus altivelis. The bacterin was prepared from the cultured cells of Pseudomonas plecoglossicida, which were killed in aceton at $37^{\circ} \mathrm{C}$ for $2 \mathrm{~h}$ and dehydrated. The experiment was performed twice in 2002 . The bacterin was orally administered to ayu (average body weight: $4.0 \mathrm{~g}$ and $3.6 \mathrm{~g}$ ) with food twice at 2-weekinterval. The fish were challenged by immersion or injection with $P$. plecoglossicida 2 weeks after the second vaccination. The bacterin showed significant efficacy with RPS of $40-79 \%$.
\end{abstract}

Keywords: bacterial hemorragic ascites, Pseudomonas plecoglossicida, oral vaccination, Plecoglossus altivelis, ayu

Pseudomonas plecoglossicidaを原因菌とするアユの 細菌性出血性腹水病（BHA） はア工養殖に打いて問題 となる疾病であり，一度発生すると哚刻な被害をもたら すことが知られている ${ }^{1)}$ 。本菌は薬郕に対してほとんど 感受性を示さないため, 化学療法郕による治療が極めて 困難であることから，予防のためのワクチン開発が切望 されている。近年, Sukenda and Wakabayashi ${ }^{2)}$ は BHA に対する浸漬ワクチンに効果があり，その有効期間は 2 回のワクチン投与で 6 週間と報告している。また，二

滋賀県水産試験場

* Corresponding author

E-mail: kintsuji-hiroaki@pref.shiga.Ig.jp
宮・山本 ${ }^{3)}$ はオイルアジュバントと混合したホルマリ ン不活化死菌（FKB）注射ワクチンに52日間の有効性が 認められると報告している。しかし，浸漬ワクチンの場 合，投与時に魚を取り上げる必要があり，これにより魚 体に傷を付けたり強度のストレスを与えてしまうことが ある。さらに，注射ワクチンの場合には麻酔や入針によ るストレスが生じてしまうばかりでなく，小さな仔稚魚 には投与が難しい。一方，経口ワクチンの場合には，餌 に均一に混合する手間は必要なものの, 魚に加わるスト レスは通常の給飭と大きく変わらない。このためアユの 場合でも養魚現場への普及の容易さの点から，経口ワク チンは浸漬や注射ワクチンより優れていると考えられ る。

これらのことから，本研究ではアユのBHA に対する 経ロワクチンの開発を試みた。

\section{材料および方法}

供試魚には琵琶湖で2001年11月および2002年 1 月に採 捕し，屋内池で飼育した湖産アユを用いた。供試魚は試 験に使用するまで水温約 $17.5^{\circ} \mathrm{C}$ の地下水を注入した $7.5 \mathrm{t}$ の 8 角形コンクリート水槽で 1 日あたり魚体重の $2 \%$ の アユ用市販飼料（日本配合飼料）を給慨して飼育した。 なお，本供試魚には実験に供するまでBHA の感染歴は なかった。供試菌には1994年にBHA で死亡したアユの 腎臓から分離したPseudomonas plecoglossicida FPC941 株 $^{1)}$ を用いた。供試菌の培養はハートインフュー ジョン液体培地（日水） $1 \mathrm{~L}$ に種菌を接種し， $25^{\circ} \mathrm{C}, 100$ $r p m$ で振蓡しながら24時間培養した。培養液は20分間の 冷却遠心分離 $\left(4^{\circ} \mathrm{C}, 8,900 \times g\right)$ を行い，沈渣を蒸留水 で泠却遠心 $\left(4^{\circ} \mathrm{C}, 16,900 \times g\right)$ により 3 回洗浄した。洗 浄後, 供試生菌の沈渣を $40 \mathrm{~mL}$ のアセトンに再浮遊させ, $37^{\circ} \mathrm{C}$ で 2 時間静置して脱水と固定を行なった。静置後, 冷却遠心分離 $\left(4^{\circ} \mathrm{C}, 16,900 \times g\right)$ により集菌し，再度 $40 \mathrm{~mL}$ のアセトンに浮遊, 遠心分離を 2 回繰り返して完 全に脱水した。遠心後，沈渣を室温で 2 時間減圧下で静 置して乾燥させ, 供試菌乾燥菌体は使用まで $4^{\circ} \mathrm{C} て ゙$ 保存 した。なお，供試菌乾燥菌体は全ての試験で同一のロッ 卜を用いた。BHA 経口ワクチンは乾燥菌体 $\left(4^{\circ} \mathrm{C}\right.$ で 2 ケ 月間保存したもの)，アユ用市販飼料拈よび市販ナタネ 油を 2:100:5の重量比で混合して調製した。

試験区および対照区として水温約 $17.5^{\circ} \mathrm{C}$ の地下水を注 入した $300 \mathrm{~L}$ 水槽に供試魚を32尾収容し，それぞれ 2 個 （合計 4 水槽）を用い，2 週間の馴致飼育を行なった後， 供試した。BHA 経ロワクチンの投与は 1 日当たり供試魚 体重の $2 \%$ 重量を 5 回 $(6: 00,9: 00,12: 30,15: 00$ および18:00）に分けて投与した。また，ワクチン投与 2 週間後に前述と同様に再度ワクチンを投与した。対照 区には乾燥供試菌体を除いた飼料を試験区と同様に与え 
Table 1. Mortalities and relative percent survivals (RPS) in ayu oraly immunized with aceton-dry Pseudomonas plecoglossicida bacterin

\begin{tabular}{|c|c|c|c|c|c|c|}
\hline Experiment & Vaccination & Challenge method & $\begin{array}{c}\text { Number } \\
\text { of fish }\end{array}$ & $\begin{array}{c}\text { Number of } \\
\text { fish died }\end{array}$ & $\begin{array}{c}\text { Mortality } \\
(\%)\end{array}$ & $\begin{array}{c}\text { RPS*1 } \\
(\%)\end{array}$ \\
\hline \multirow{4}{*}{ First Exp. } & Immunized & Immersion $\left(1.1 \times 10^{6} \mathrm{CFU} / \mathrm{mL}\right)^{* 2}$ & 25 & 8 & $32 * 4$ & 66.7 \\
\hline & Control & & 25 & 24 & 96 & - \\
\hline & Immunized & Injection $\left(1.1 \times 10^{3} \mathrm{CFU} / \mathrm{fish}\right)^{* 3}$ & 25 & 12 & $48^{* 4}$ & 47.8 \\
\hline & Control & & 25 & 23 & 92 & - \\
\hline \multirow{4}{*}{ Second Exp. } & Immunized & Immersion $\left(1.2 \times 10^{6} \mathrm{CFU} / \mathrm{mL}\right)^{* 2}$ & 25 & 12 & $48^{*} 4^{-}$ & 40.0 \\
\hline & Control & & 25 & 20 & 80 & - \\
\hline & Immunized & Injection $\left(6.3 \times 10^{3} \mathrm{CFU} / \mathrm{fish}\right)^{* 3}$ & 25 & 4 & $16^{* 4}$ & 78.9 \\
\hline & Control & & 25 & 19 & 76 & - \\
\hline
\end{tabular}

$* 1$ RPS $=(1$-Mortality of vaccinated fish/Mortarity of unvaccinated fish $) \times 100$.

*2 The fish were challenged by soaking for 10 min with $P$. plecoglossicida.

*3 The fish were challenged by intraperitoneally injection with $P$. plecoglossicida at a dose as shown above.

*4 Significant difference from control ( $p<0.01$, Fisher's exact probability)

First experiment were performed in January, 2002, and second were in July, 2002.

\section{て飼育した。}

初回ワクチン投与 4 週間後, 試験区および対照区から 25尾を取り上げ浸漬法および注射法で攻撃試験を行なっ た。浸漬法では地下水 $\left(17.5^{\circ} \mathrm{C}\right)$ で希釈した $P$. plecoglossicida 培養液 ( 1 回目 $1.1 \times 10^{6} \mathrm{CFU} / \mathrm{mL}, 2$ 回 目 $\left.1.2 \times 10^{6} \mathrm{CFU} / \mathrm{mL}\right)$ に10分間浸漬し, 注射法では $P$. plecoglossicida 培養液を生理食塩水で希勫して供試魚の 腹腔内に接種（ 1 回目 $1.1 \times 10^{3} \mathrm{CFU} / \mathrm{fish}, 2$ 回目6.3×

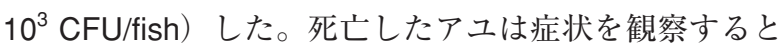
ともに細菌検査を行なってBHAによる死亡を確認した。 累積死亡率は攻撃開始から21日後に算出し, 試験区と対 照区の差はFisherの直接確率計算法により判定した。ワ クチンの有効率（Relative percent survival：RPS）は Croy and Amend ${ }^{4)}$ にしたがって算出した。

なお，試験は 2 回，すなわち 1 回目は2002年 1 月（試 験開始時の供試魚平均体重 $4.0 \mathrm{~g} ） に, 2$ 回目は2002年 7 月（平均体重 $3.6 \mathrm{~g}$ ）に実施した。

\section{結果および考察}

攻撃試験の結果を Table 1 に示した。1 回目の浸漬お よび注射攻撃試験ではワクチン接種区の死亡率はそれぞ れ32および48\%であり対照区の96抒よび92\%より有意 $(p<0.01)$ に低かった。RPSは66.7および47.8\%であっ た。2 回目の攻撃試験ではワクチン接種区の死亡率はそ れぞれ48および16\%で対照区の80および76\%より有意 $(p<0.01)$ に低かった。RPS は40.0および78.9\%であっ た。以上の結果より, 2 回の試験ともに, ワクチン処理 の効果が示され，今回作製したアセトン乾燥経口ワクチ ンはBHA に対して有効であると考えられた。また，攻 撃方法の違いにより有効性に差は認められなかった。な お，浸漬法による攻撃では攻撃12日後から出血性腹水を 伴う死亡を確認した。注射法による攻撃ではワクチン接 種区㧍よび対照区ともに出血性腹水は認められず攻撃後 3〜6 日の間に死亡が認められた。

2 回の試験で有効率には比較的大きなばらつきが認め られたが，これは供試魚の摂餌の違いによりワクチンの 摂取量に差が生じたためと考えられた。そうであるとす ると，ワクチンの投与方法の改良またはワクチン投与回 数を増やすことなどによって有効性はさらに安定すると 考えられる。今回の試験ではアセトン乾燥法でワクチン を作製したが，今後，通常用いられるFKB 等で作製し たワクチンとの有効性の比較が必要と考えられる。

本稿を校閲頂いた滋賀県水産試験場の藤岡康弘博士に 深謝する。

\section{文献}

1）若林久嗣 - 沢田健蔵・二宮浩司・西森 栄 (1996)：魚病研 究, 31, 239-240. 2) Sukenda and H. Wakabayashi (1999)： Fish Pathol., 34, 163-164. 3) 二宮浩司 - 山本充孝（2001）: 魚病研究, 36, 183-185. 4) Croy, T. R. and D. F. Amend (1977): Aquaculture, 12, 317-325. 